\title{
Relation of Plasma Coagulation Factor VII and Fibrinogen to Carotid Artery Intima-Media Thickness
}

\author{
M. N. Sosef', J. G. Bosch², J. van Oostayen², T. Visser', J. H. C. Reiber², \\ F. R. Rosendaal 3
}

From the 'Department of Clinıcal Epıdemılogy, '2Department of Diagnostıc Radıology, and ${ }^{3}$ Hemostasis and Thrombosis Research Center, University Hospital Leiden, The Netherlands

\section{Summary}

Plasma clotting factor VII and plasma fibrinogen have been claimed as independent $11 \mathrm{sk}$ factors for occlusive cardiovasculat disease The aim of this study was to investigate whether these coagulation parameters affect early atheioscleiosis, additional to their possible effect on at terial thrombosis

We used high-iesolution quantitative ultrasonography to measute carotid intıma-media thickness in 121 healthy volunteers, aged 18 to 56 years It has previously been demonstiated that an increased aitery wall thickness is seen in advanced atheroscleiosis To validate our method ology for relatively young individuals, we assessed the association of intıma-media thickness with the risk-factor status of our subjects, by including classical cardiovascular risk factors, e g age, sex, serum cholesterol, smoking habits and blood pressure Theieafter, we studied the effect of factor VII and fibrinogen plasma levels on carotid intımamedia thickness, as well as that of polymorphisms of the factor VII and fibrinogen genes

All classical usk factors except smoking and family history were associated with intima media thickness When adjusted for by mult1variate linear regiession analysis, age, blood piessure and cholesterol appeared to be independent determınants of intıma-media thickness Factor VII and fibrinogen levels showed no association in multıvariate analysis with intıma-media thickness We conclude that aitery wall thickness measurement by ultrasound is a useful tool to investigate the role of clotting factors in early atherosclerosis Factor VII and fibunogen levels in young and middle-aged voluntees have no association with early atherosclerotic vessel wall changes

\section{Introduction}

A telation between high levels of coagulation factors as factor VII and fibinogen and the 11sk of ischaemic heart disease has been shown in several studies Theiefore, coagulation parameters have been suggested to be independent 11sk factors for occlusive cardiovascular disease (1-4) Occlusive cardiovascular disease generally or 1 ginates from thrombus formation on an atheroscleiotic plaque it is the result of a decades-long chronic atherosclerotic process, combined with the acute phenomenon of arterial thrombosis (5) The clotting factor level may have an effect on the progression of atherosclesosis, on arterial thrombosis, or on both

Correspondence to Di F R Rosendaal, Department of Clinical Epide miology, Building 1, CO-P-46, Unıveisity Hospital Leiden, P O Box 9600, N-2300 RC Leiden, The Netherlands - FAX Numbel +3171248122
The aim of this study was to assess iecent methodology in the evaluation of the role of fibrinogen and clotting factor VII in the very eatly stage of atherosclerosis, before progression to atherosclerotic plaques or thrombus formation Specifically, we sought for a non-invasive, easy-to-use method to assess the role of clottıng factors in atheiosclerosis We used high-resolution ultrasonography to measure carotid aitely intıma-media thickness with the computer-based Cardiovascular Measurement System (CMS) Intima-media thickness measuied with ultiasound has been shown to be a 1eliable indicator of the atherosclerotic process (6-8) with a high concordance of the ultrasound measurement and pathologic evaluation (9) Most studies, however, have been peiformed in older subjects who either suffered from arteiral disease or belonged to a specific risk group (e g hypeicholesterolemic patients) We were intelested in the use of this method in the earliest stage of atheroscletotic vessel wall changes Therefore, as a validation, we assessed the association between classic risk factors and intımamedia thickness in young and middle-aged adults Only after this yielded satısfactory results, did we proceed to investigate the role of clotting factor levels in these subjects

First, plasma levels of clottıng factor VII and of fibrinogen were determined to study theil relation with caiotid intıma-media thickness These clottıng factor levels, however, may have been affected by extraneous factors that also enhance atherosclerosis, 1 e age, smokıng habits and lipids Therefore, we adjusted for these factors by multıvariate analysis Of course, this only allows adjustment for extraneous influences that are known and can be measured accurately

A second option to adjust for confounding factors lies in the determination of polymorphisms of the factor VII and fibrinogen genes As has been reported recently, several of these polymoiphisms are assoc1ated with the plasma levels of the clotting factors These include a HaellI polymoiphism (alleles $\mathrm{H} 1$ and $\mathrm{H} 2$ ) for the $\beta$-chain of fibrinogen (10) and a MspI polymorphism (alleles M1 and M2) in the factor VII gene (11) The H2-allele was found to be assocrated with higher than average tibunogen levels, and the M2-allele with lower than average levels of factor VII Obviously, these polymorphisms cannot be influenced by extraneous factors, and therefore they offer the possibility to study the effect of clotting factor levels, unaffected by external factors as smoking, lipid levels or even the atheroscleıtic process itself

\section{Materials and Methods}

\section{Study Design}

We studied 121 healthy volunteers, aged 19-56 years They were all free of clinical signs of cardiovascular disease, diabetes mellitus or any other chronic disorder, and did not use anticoagulants or lipid-lowerng drugs Use of oral 
contraceptives was not an exclusion citeison We measured intımd media thickness (IMT) of the carotid arteries, classical cardiovascular 11sk factors and plasma levels of factor VII and fibrinogen In addition, we determıned polymorphisms of the factor VII and fibrinogen genes

\section{Asscssment of Carotul Inttma-media Thuckness}

Ultrasonographic scanning of the carotid atteries was petformed with the Aloka Echo Camera SSD 650 equipped with a high density linear drray piobe with $75 \mathrm{MHz}$ transducer fiequency in B mode The axial resolution was at least $03 \mathrm{~mm}$ The subjects wele lying in a supine position with the head slightly extended and iotated 45 degrees away from the side which was scanned Scanning was performed in the anteroposterior plane, imaging the caiotid bifurcation and the common carotid arteiy Three B mode images of the left and right common caroud artery were fiozen at peak diastole on sight, and recorded on a SVHS video cassette tape Images were coded to ensure that latel intıma media thickness (IMT) measurements were performed blinded for subjects' identity, coagulation factor levels or risk factor status

Intima media thickness was measured later on in one session for all sub jects with the Cardıovascular Measurement System (CMS) (12) Frozen ımages wete digitized at a resolution of $512 \times 512$ pixels with 8 bits of grey levels $\mathrm{Ca}$ libration of the images was performed by manually identıfying a $4 \mathrm{~cm}$ distance on a $\mathrm{cm}$ scale in the image, typical pixel size in the nonmagnified mode was $01 \mathrm{~mm} \mathrm{~A}$ one centimeter traject of the posterior carotid wall one centumeter proximal to the caroud bifurcation was enlarged four times by cubic spline in terpolation Next six intıma-media thickness measurements were performed over this one centımeter range at 6 measurement sites in each recording The thickness of the intıma-media complex as defined by Pignoli (6) was measuied as the distance between the lumen intıma interface and the media adventitia interface on the B-mode image The actual measurement at each of these six sites was carried out with the digital calıper on the CMS The intima-media thick ness at each of the six measurement sites was determined by manually defining one pair of points at each measurement site and by averaging these six distance measures This multiple measurement approach results in a high degree of ac curacy and precision In this way in each subject 36 intıma media thickness measurements ( 6 measurements $\times 6$ images) were performed, the average value of these 36 measurements was defined as the intıma media thickness (IMT) in each subject

\section{Other Measurements}

Information on subject's smoking habits (current smoking, package years of cigarette smoking) and presence of cardiovascular disease in first-grade rela tives before the age of 60 years (history of myocardial infarction, intermittent claudication) were obtained by means of a questionnaire Famıly history was coded as etther negative or positive Body mass index was calculated as Quetelet index ( $\mathrm{wt} / \mathrm{ht} \mathrm{t}^{2} \mathrm{in} \mathrm{kg} / \mathrm{m}^{2}$ ) Systolic and diastolic blood piessure were measured three times in each subject before venepuncture with a Hawksley random 7ero mercury sphygmomanometer after a minmum of ten minutes of rest The mean was used in the analysis

In fresh blood samples total serum cholesterol and HDL serum cholesterol concentration were determined by standard enzymatic assays, aganst the WHO standard Plasma fibrinogen concentration and plasma clottung factor VII activity were determined by the methods according to Clauss (13) (Cibrinogen, $\mathrm{g} / \mathrm{l}$ ) and Owren (14) (factor VII, \% of standard) Polymorphisms of the $\beta$-chan of fibrinogen and of factor VII were determined with the use of HaellI and MspI restriction enzymes as reported by Thomas (10) and Green (11) The alleles with the restriction site were designated $\mathrm{H} 1$ (fibrinogen) and $\mathrm{M} 1$ (Factor VII), and the non-cleavable alleles were designated H2 and M2

\section{Statistical Analysts}

We analysed the relation of the factors of interest with caroud wall thickness by linear regression techniques The regression coefficient obtained by this method, indicates the increase (or decrease, dependent on the sign of the coef ficient) in intima media thickness per unit increase in the factor studied All continuous variables (e g blood pressure, cholesterol, age) were entered into the regiession equation as such, and therefore the coefficients indicate the change in wall thrckness (in $\mu \mathrm{m}$ ) pei one $\mathrm{mmHg}$ increase in blood piessure one $\mathrm{mmol} / \mathrm{l}$ mciease in cholesterol and one year increase in age To facilitate intelpretation and comparison between variables we calculated the change in intı ma medıa thickness for meaningful increments of the independent variables, 1 e $10 \mathrm{mmHg}$ for blood piessure $1 \mathrm{mM}$ for cholesterol, 10 yeat s for age and 10 package-years for smoking The original regression coefficients can easily be derived by dividing the change in IMT by 10 for blood pressure, age and pack age-years Discrete vaurables werc coded as 0 or 1 In this instance the regression coefficient indicates the difference in intima medid thickncss between the two categones

Since several of the variables may be associated, we subsequently set up a multivariate model which yields mutually adjusted iegression coefficients

\section{Results}

\section{Baseline Values and Relattons between Determinants}

Baseline characteristics in ou study showed the expected mean values for healthy subjects, with a broad range that facilitated the evaluation of possible effects of risk factors (Table 1)

The average carotid intıma media thickness was $519 \mu \mathrm{m}$ (SD 72, 1ange 397-781 $\mathrm{mm}$ ) Left and right intıma media thickness showed a Pearson correlation coefficient of $r=083$, with average values of 521 $\mu \mathrm{m}$ and $517 \mu \mathrm{m}$, respectively

Several of the determinants were interrelated Factor VII plasma level was associated with sex (mean $994 \%$ in men, and $1114 \%$ in women), and was positively conelated with the total cholesteiol level (regression coefficient $64 \%$ FVII per mmol/l cholesteiol) and fibrinogen level (regression coefficient 158\% FVII pes g/l fibrinogen) Fibrinogen showed, in addition to 1ts association with the factor VII level, increasing values with age (regression coefficient $013 \mathrm{~g} / \mathrm{l}$ per $10 \mathrm{yr}$ ) Systolic and diastolic blood pressure were higher in men than in women (mean SBP $124 \mathrm{mmHg}$ in men, and $117 \mathrm{mmHg}$ in women, mean DBP $81 \mathrm{mmHg}$ in men, and $76 \mathrm{mmHg}$ in women), and in the obese (regression coefficient $18 \mathrm{mmHg}$ systolıc and $16 \mathrm{mmHg}$ diasto lic per $\mathrm{kg} / \mathrm{m}^{2}$ )

\section{Clotting Factor Gene Polymorphism and Clotting Factor Plasma Levels}

The MspI polymorphısm of factor VII had an allele-fiequency fot the M2 allele of ten percent, 18 percent of the individuals were carriers

Table I General characteristics of 121 healthy voluntees

\begin{tabular}{lcrrc}
\hline Valiable & $\mathrm{n}$ & Mean & (SD) & Range \\
\hline Sex male & 64 & & & \\
$\quad$ female & 57 & & & \\
Age (yrs) & & 345 & $(92)$ & $19-56$ \\
Plasma fibrnogen (g/l) & 29 & $(06)$ & $18-44$ \\
Plasma factor VII act (\%) & & 1051 & $(263)$ & $51-196$ \\
Systolic BP (mmHg) & 1203 & $(144)$ & $89-167$ \\
Diastolic BP (mmHg) & 786 & $(105)$ & $51-106$ \\
Serum cholesterol (mM) & 54 & $(11)$ & $30-90$ \\
Serum HDL-cholesterol (mM) & & 15 & $(04)$ & $07-26$ \\
Smoking (package years) & & 31 & $(84)$ & $0-65$ \\
Quetelet index (kg/m²) & & 236 & $(29)$ & $176-336$ \\
Fam history neg & 100 & & & \\
Fam history pos & 21 & & & \\
\hline
\end{tabular}


Table 2 Factor VII and tibı inogen polymorphisms and plasma levels

\begin{tabular}{llrrrr}
\hline & & $n$ & $\begin{array}{c}\text { Perc of } \\
\text { subjects }\end{array}$ & $\begin{array}{l}\text { Mean clotting } \\
\text { factor level }\end{array}$ & (SD) \\
\hline Factot VII & M1M1 & 99 & $(82 \%)$ & $1096 \%$ & $(260)$ \\
& M1M2 & 19 & $(16 \%)$ & $851 \%$ & $(175)$ \\
& M2M2 & 3 & $(2 \%)$ & $823 \%$ & $(64)$ \\
F1brinogen & H1H1 & 86 & $(71 \%)$ & $288 \mathrm{~g} / 1$ & $(58)$ \\
& H1H2 & 33 & $(27 \%)$ & $286 \mathrm{~g} / 1$ & $(55)$ \\
& H2H2 & 2 & $(2 \%)$ & $360 \mathrm{~g} / 1$ & $(74)$ \\
\hline
\end{tabular}

Table 3 Unıvanate 1egression analysis of risk factors

\begin{tabular}{|c|c|c|}
\hline Varıable & $\begin{array}{l}\text { Change in } \\
\text { IMT }(\mu \mathrm{m})\end{array}$ & $\begin{array}{l}95 \% \text {-confidence } \\
\text { interval }\end{array}$ \\
\hline Age (10 y1s) & 377 & 254 to 502 \\
\hline $\operatorname{Sex}(m=0, f=1)$ & -286 & -540 to -32 \\
\hline Systolic BP (10 mmHg) & 179 & 95 to 263 \\
\hline Diastolic BP $(10 \mathrm{mmHg})$ & 216 & 98 to 338 \\
\hline Serum cholesterol (1 mM) & 232 & 122 to 342 \\
\hline Serum HDL-cholesteiol (1 mM) & -210 & -517 to 97 \\
\hline Cholesterol/HDL-cholesterol ratio & 175 & 90 to 260 \\
\hline Smokıng (10 package years) & 66 & -8810220 \\
\hline Quetelet index $\left(1 \mathrm{~kg} / \mathrm{m}^{2}\right)$ & 66 & 22 to 110 \\
\hline Fam history (neg $=0$, pos $=1$ ) & -138 & -479 to 203 \\
\hline Plasma fibunogen $(1 \mathrm{~g} / \mathrm{l})$ & 2070 & -16 to 430 \\
\hline Factoi VII activity $(10 \%)$ & 20 & -29 to 69 \\
\hline Fibrinogen polymoiphısm $\mathrm{H} 1 \mathrm{H} 2 / \mathrm{H} 2 \mathrm{H} 2$ & -256 & -537 to 26 \\
\hline Factor VII polymoiphısm M1M2/M2M22 & -78 & -414 to 257 \\
\hline
\end{tabular}

Increment compared to $\mathrm{H} 1 \mathrm{Hl}$ genotype

${ }^{2}$ Inciement compared to M1M1 genotype

of an M2-allele Those who catried this allele had about 20 percent less factor VII activity (Table 2)

The HaeIII polymoiphism of fibrunogen had an allele-frequency for the $\mathrm{H} 2$-allele of 15 percent, 29 percent carried a $\mathrm{H} 2$-allele Contrary to the findings of Thomas et al (10), canlers of the $\mathrm{H} 2$-allele did not have higher plasma fibinogen levels than those homozygous for the H1allele (the level appeared highet in individuals who were homozygous for the H2-allele, but this included only two individuals)

Based on these data, we concluded that the MspI factor VII polymotphism was a valuable indicator of the "genetic factor VII level"

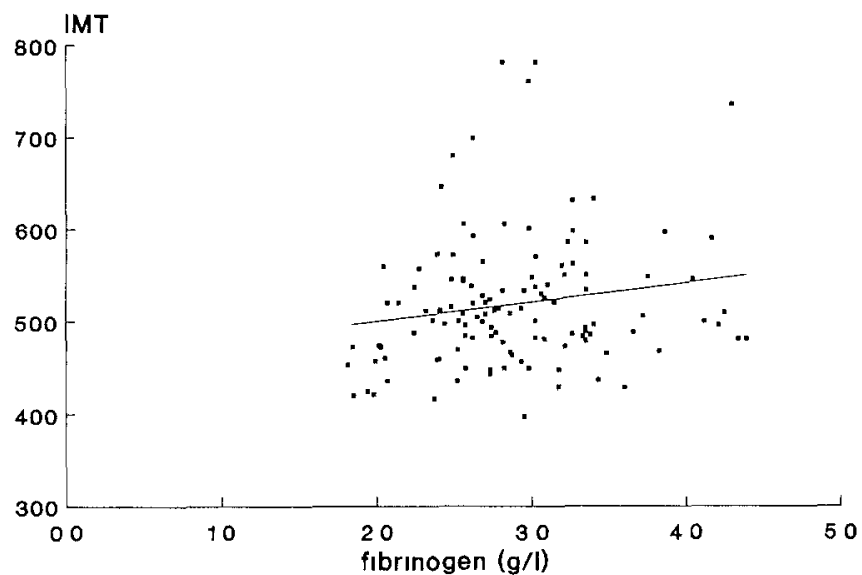

The HaeIII fibınogen polymorphism did not fulfill our expectations in this respect

\section{Relation of Determinants and Vessel Wall Thickness}

The intıma-media thickness of the carotid arte1y (mean of 18 measulements at each side), was hıgher for men than for women, and increased with age, blood pressure (both systolic and diastolic), total ser um cholesterol, cholesterol/HDL ratı and Quetelet-1ndex, whereas it decreased with HDL-cholesterol (Table 3) No relation with packageyears of smoking, nor with a positive family histoly of cardiovascular disease was found

The intıma-media thickness increased with higher levels of fibrinogen, whereas the fibinnogen polymorphism showed a strong trend of association with intıma-media thickness, albeit in the unexpected direction (lower IMT for carrers of the H2-allele) Intima-media thickness was not related to factor VII activity, nor to the factor VII polymorphism genotype (Table 3) Scatterplots of factor VII and fibınogen versus intıma-media thıckness with the regression lines are depicted in figure 1 It may be noted that the association of IMT with fibrinogen levels (207 $\mu \mathrm{m}$ per $1 \mathrm{~g} / \mathrm{l}$ increase in fibrinogen) was to a high extent determined by one outlying observation Leaving out this point (fibrinogen $426 \mathrm{~g} / \mathrm{l}$, IMT $752 \mu \mathrm{m}$ ) 1educed the slope of the tegression line to $137 \mu \mathrm{m}$ pe1 $1 \mathrm{~g} / \mathrm{l}$ (CI95 -85 to $360 \mu \mathrm{m}$ per $\mathrm{g} / \mathrm{l}$ increase in fibrinogen)

\section{Multwariate Analysis}

Since several of the determinants appeared to be interrelated, we performed a multivaridte regression analysis The iegression coefficients of this analysis are to be inteipreted simila1ly to those of a simple unvariate regression, but now the effects of other variables are adjusted for

When all classical determinants were entered into the model, age, blood pressule, total cholesterol and HDL-cholesterol emerged as independent determinants of intıma-media thickness When diastolıc blood pressure was entered in the analysis instead of systolic blood pressure, the diastolic regression coefficient became $110 \mu \mathrm{m} / 10 \mathrm{mmHg}(95 \%$ $\mathrm{CI}-090$ to 22 9) The effect of sex was attenuated as was that of fibrinogen, whereas the Quetelet index had no independent effect, nor had factor VII plasma levels In this analysis, as in univanate analysis, no effect of smoking or a positive family history could be observed (Table 4)

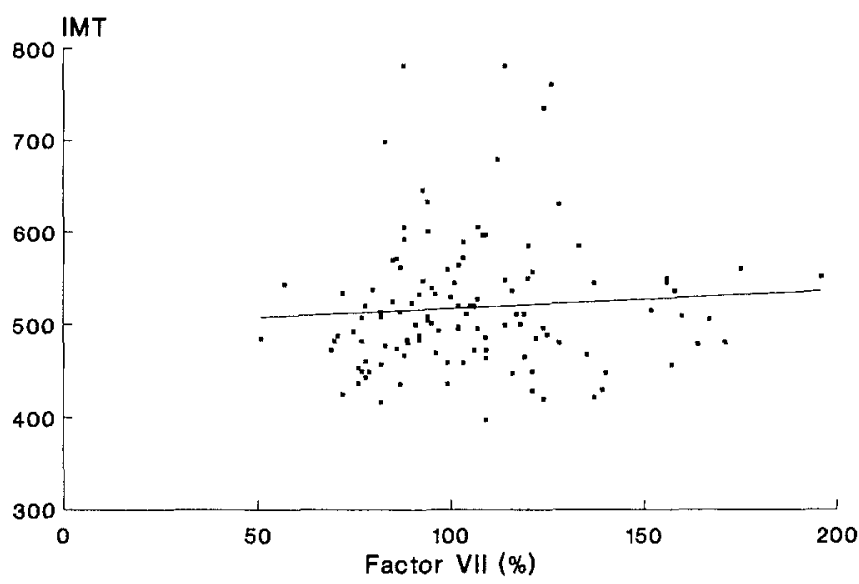

Fig 1 Scatteiplot of fibıinogen (left) and factor VII (11ght) with intima-media thickness The regiession line is indicated in the figures (fibinogen $459+207 \times$ fibınogen level, factor VII $498+20 \times$ factor VII level) 


\section{Discussion}

We performed a cross sectional study to assess whether ultrasound measurement of carotid artery wall thickness could be of value in investigating the role of clotting factor levels in the development and progression of atherosclerosis

Intima-media thickness was clearly associated with several classical cardiovacular risk factors like age, sex, systolic and diastolic blood pressure, total and HDL serum cholesterol All these associations were positive or negatıve according to the expected (15) effect of the riskfactor on atherosclerosis Although the effects themselves are small, the associations are more than striking, since they were observed in a small study of a heterogeneous group of mostly young individuals We therefore conclude that ultrasonographic assessment of carotid intima-media thickness offers itself as a valuable research tool for non-invasive measurement of early atherosclerosis in healthy young and middleaged subjects, as it is applied in studies with elderly or symptomatic subjects

It is notable that at the relative young age of our subjects, alterations were already visible in the arterial vessel wall, in a clear association with the presence or absence of cardiovascular risk factors

Information fiom the literature about IMT in young healthy individuals is very scarce When we compare our results to those of the healthy control groups in two other studies $(7,16)$, the mean intimamedia thıcknesses are very simular (about $05 \mathrm{~mm}$ ), as is the age relation compared to two studies that also included young subjects $(6,17)$ Interestingly, a much higher mean IMT of $1 \mathrm{~mm}$ was found in the Kuopro Ischdemic Heart Disease Risk Factor Study (8), which is conducted in an area with a very high incidence of coronary artery disease (eastein Finland) No comparison can be made on the effects of risk factors on intıma-media thickness in young subjects, as no such studies could be found in the literature

We did not find associations of artery wall thickness with cardiovascular family history, nor with smoking, which is not in accordance with several other studies in which an effect of smoking on IMT had been found $(7,16)$ Although it has to been borne in mind that most studies on IMT, including ours, have been quite small which may easily have led to differences due to chance varration, it cannot be ruled out that these well-established risk factors for atherosclerosis may have a delayed effect, which will therefore not yet be apparent in young individuals

Our study showed no association of the level of factor VII, or its polymorphism with intıma-media thickness Even in view of the limited number of subjects, an important effect of factor VII seems unlikely from these data This is less clear for fibrinogen Univariate analysis indicated a relation of fibrinogen with intima-media thickness that was (per $1 \mathrm{~g} / \mathrm{l}$ ) of about the same magnitude as for serum cholesterol (per $1 \mathrm{mM}$ ) This association largely disappeared in the multivanate analysis, which may be the result of correlations with other variables, especially age, on the other hand, it cannot be ruled out that part of the effect of age is mediated by fibrinogen Finally, the confidence intervals for the association of fibrinogen levels and artery wall thickness remained wide, and do not allow firm conclusions

The fibrinogen polymorphism had no relation with plasma fibinogen levels in these 121 Dutch volunteers, whereas it was a clear predıctor of fibrinogen levels in two studies among British and Fiench indıv1duals $(9,18)$ Recently, we also falled to find this association in an independent sample consisting of 199 patients with deep venous thrombosis and 199 healthy contiols (19) Apparently, the association between this polymorphism and fibrinogen levels is not universal We did
Table 4 Multivariate regression analysis

\begin{tabular}{lcl}
\hline Variable & $\begin{array}{l}\text { Change in } \\
\text { IMT }(\mu \mathrm{m})\end{array}$ & $\begin{array}{l}95 \% \text {-confidence } \\
\text { interval }\end{array}$ \\
\hline Age $(10 \mathrm{yrs})$ & 302 & 173 to 430 \\
Sex $(\mathrm{m}=0, \mathrm{f}=1)$ & -118 & -388 to 152 \\
Systolic BP $(10 \mathrm{mmHg})$ & 110 & 26 to 194 \\
Cholesterol $(1 \mathrm{mM})$ & 140 & 30 to 250 \\
HDL-cholesterol $(1 \mathrm{mM})$ & -215 & -532 to 103 \\
Smoking $(10$ package-years $)$ & -064 & -138 to 125 \\
Quetelet 1ndex $\left(1 \mathrm{~kg} / \mathrm{m}^{2}\right)$ & -13 & -59 to 33 \\
Fam history (neg $=0$, pos $=1)$ & -154 & -451 to 143 \\
Plasma fibrinogen $(1 \mathrm{~g} / \mathrm{l})$ & 96 & -113 to 305 \\
Plasma factor VII act $(10 \%)$ & -032 & -53 to 47 \\
\hline
\end{tabular}

find a 1elation between the HaeIII polymorphısm and IMT, whıch was in the unexpected direction ( 1 e lower IMT in carriess of the H2-allele) Obviously, since the polymorphism and the fibrinogen level were not associated, this effect cannot be interpieted as mediated by the plasma level Still, thıs findıng provokes thought, especially given ou pievious study on venous thrombosis (40 percent reduction of 11sk in $\mathrm{H} 2$ carriers) (19), and the results of the ECTIM study (10-20\% reduction of myocardial infarction risk for those who carıed the H2-allele) (18)

These findings suggest that factor VII and fibrinogen have no detectable influence on early atherosclerosis Obviously, our study offers no information of the effect of clotting factor levels in advanced atherosclerosis with plaque formation We have studied healthy volunteeis with clotting factor levels that generally were in the usual ange We cannot exclude therefore, that extreme values of factor VII or fibrinogen (either at the lower or upper extreme of the spectrum) may have a noticeable and relevant effect on atherosclerosis

Our method of measuring atheroscleiosis can be extended to othet superficial arteries such as the femoral or popliteal, although it is likely that for reseatch purposes measurements at the catotid arteries ate sufficient for an adequate overall picture (20) We believe that automatic (off-1ine) detection of intima-media boundaries and contours could further impiove the accuracy and precision of our measurements In addition, arterial vessel wall compliance may offer additional information in descubing atheroscleiosis

Intıma-media measurements are valuable in young and middle-aged subjects, to study the determinants of atheroscleiosis in its earliest stages Our study offers no support for the hypothesis that the clottıng factor system is involved in the development and progiess of early atheiosclerosis

\section{Acknowledgements}

We wish to thank Di J Schipper and Dı N Matthıssen for thei technical assistance with the ultrasonography, Di J Souverijn for his suppott in the lipid measurements and P A van der Velden and Di P H Retsma for the DNA analysis We also acknowledge the contubutions tiom Prof Dr J P Vanden broucke and Prof Dr E Buet We are very indebted to all volunteers for then kind cooperation

\section{References}

1 Wilhelmsen L, Svardsudd K, Korsan Bengtsen K, Larsson B, Welın L, Tibblın G Fibunogen as a 11sk factor for stroke and myocardial infarction N Engl J Med 1984, 311 501-5 
2 Kannel WB, D'Agostuno RB, Belanger AJ Fibrunogen, crgarette smoking, and risk of cardiovascular disease insights from the Framingham Study Am Heart J 1987, 113 1006-10

3 Meade TW, Mellows S, Brozovic M, Miller GJ, Chakıabarı RR, North WRS, Haines AP, Stıling Y, Imeson JD, Thompson SG Haemostatic function and ischaemic heart disease puncipal results of the Northwick Park Heart Study Lancet 1986, 11 533-7

4 Balleısen L, Schulte H, Assman G, Epping PH, Loo J van de Coagulation factors and the progress of coronary heart disease Lancet 1987, 11461

5 Ross R The pathogenesis of atherosclerosis - an update N Engl J Med 1986,314 488-500

6 Pignolı P Uitrasonic evaluation of arterial intıma and media thıckness Development and validation of methodology In Pathobiology of the human atherosclerotic plaque (pp 705-732) Glagov S, Newmann WP, Schaffer SA, eds Springer Verlag, New York, 1990

7 Polı A, Tremolı E, Colombo A, Strtorı M, Pignolı P, Paolettı R Ultrasonographic measurement of the common carotid artery wall thickness in hypercholesterolemic pattents Atheroscler 1988, 70 253-61

8 Salonen R, Salonen JT Piogression of carotid atherosclerosis and its determinants a population based ultrasonography study Atheroscler 1990, 81 $33-40$

9 Pıgnolı P, Tremolı E, Polı A, Oreste P, Paolettı R Intımal plus medial thickness of the arterial wall a direct measurement with ultrasound $1 \mathrm{~m}$ aging Circulation 1986, 74 1399-1406

10 Thomas AE, Green FR, Kelleher CH, Wilkes HC, Brennan PJ, Meade TW, Humphries SE Variation in the promotor region of the $\beta$ fibrinogen gene is associated with plasma fibrnogen levels in smokers and non-smokers Thromb Haemost 1991, 65 487-90

11 Green F, Kelleher C, Wilkes H, Temple A, Meade T, Humphries S A common genetic polymorphism associated with lower coagulation factor VII levels in healthy individuals Arterioscler Thromb 1991, 11 540-6
12 Koning G, Reiber JHC, Land CD von, Loo1s G, Meurs B van Advantages and limitations of two software calipers in quantitative coronary arteriography Int J Card Imaging 1991, 7 15-30

13 Clauss A Germnungsphysiologische Schnellmethode zu1 Bestımmung des Fibrinogens Acta Haematol 1957, 17237

14 Owren PA A quantitatıve one-stage method for the assay of prothrombin Scan J Clin Lab Invest 1949, 181

15 Hopkıns PN, Williams RR Identification and relative weight of cardıvascular rısk factors Cardıol Clın 1986, 4 3-31

16 Markussis V, Beshyah SA, Fisher C, Sharp P, Nicolardes AN, Johnston DG Detection of premature atherosclerosis by high-resolution ultrasonography in symptom-free hypopituitary adults Lancet 1992, 340 1188-92

17 Handa N, Matsumoto M, Maeda H, Hougaku H, Ogawa S, Fukunaga R, Yoneda S, Kımura K, Kamada T Ultrasonic evaluation of early carotid atherosclerosis Stroke 1990, 21 1567-72

18 Scarabin PY, Bara L, Ricard S, Poirier O, Cambou JP, Arveıler D, Luc G, Evans AE, Samama MM, Cambien F Genetic variation at the $\beta$-fibrinogen locus in relation to plasma fibrinogen concentrations and risk of myocardaal infarction the ECTIM study Arterioscler Thromb 1993, 13 886-91

19 Koster T, Rosendaal FR, Reitsma PH, Velden PA van der, Briet E, Vandenbroucke JP Factor VII and fibrinogen levels as risk factors for venous thrombosis A case-control study of plasma levels and DNA polymorphisms - The Leiden Thrombophlla Study (LETS) Thromb Haemost 1994, 71 719-22

20 Sutton KC, Wolfson SK, Kuller LH Carotid and lower extremity arterial disease in elderly adults with 1solated systolic hypertension Stroke 1987, 18 817-22

Recerved January 6, 1994 Accepted afteı revision March 31, 1994 